
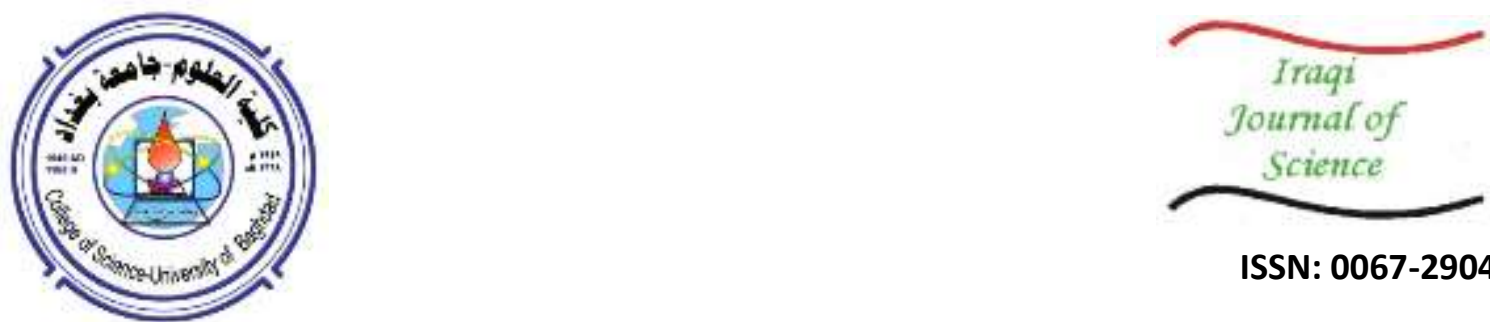

ISSN: 0067-2904

\title{
Assessment of Soil Pollution in the Ishaqi Project Area- Salah Al-Dean Governorate, Iraq
}

\author{
Moutaz A. Al-Dabbas, Marwa A. Abdullah* \\ Department of Geology, College of Science, University of Baghdad, Baghdad, Iraq
}

Received: 28/7/ 2019

Accepted: 28/ 8/2019

\begin{abstract}
Ten soil samples were collected from Ishaqi project area, Salah Al-Dean Governorate, and analysed for chemical elements (Fe2O3, Al2O3, CaO, K2O Na2O, $\mathrm{Co}, \mathrm{Zn}, \mathrm{Cu}$, and $\mathrm{Pb}$ ) to detect the pollution in the study soil using the indices of geoaccumulation (I-geo), contamination factor (CF), and pollution load index (PLI), The results of I-geo indicate that the soil of Ishaqi project area is unpolluted with $\mathrm{Pb}$, $\mathrm{Co}$ and slightly polluted with $\mathrm{Zn}$ and $\mathrm{Cu}$. The results of $\mathrm{CF}$ for $\mathrm{Zn}, \mathrm{Cu}$, and $\mathrm{Co}$ showed class 2 of moderate contamination and class 1 of low contamination in some samples while those for $\mathrm{Pb}$ demonstrated class 1 -of low contamination. The Pollution Load Index (PLI) values for $\mathrm{Co}, \mathrm{Zn}, \mathrm{Cu}$, and $\mathrm{Pb}$ showed class 2 of local pollution.
\end{abstract}

Keywords: Geo-accumulation, Contamination factor, Pollution load index, Ishaqi soil.

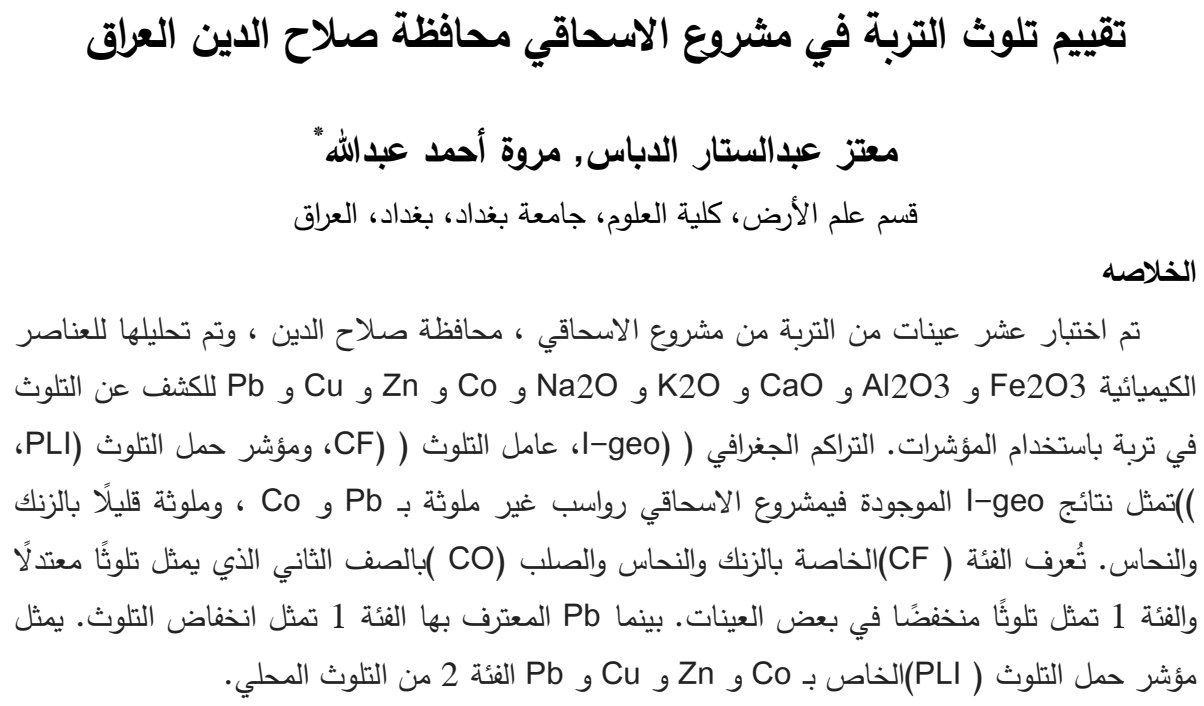

\section{Introduction}

High probability of heavy elements contamination is expected from exhaust gases of vehicles, emissions from factories, regional / local sand and dust storms. Toxic heavy elements affecting the ecosystems could lead to geo-accumulation and bioaccumulation [1]. Pollutants enter the environment in many ways, such as by industrial discharge, municipal waste discharge and others; also by land runoff mainly by rivers, tributaries, agricultural canals and by the atmospheric fallout of pollutants transferred by the air mass onto the land- surface [2]. Many authors studied the heavy elements as a 
polluted indicator using the traditional analytical methods [3], but neither one used the proposed indices to evaluate the pollution and the degree of weathering of study area soil, central Iraq. Ishaqi project area is located about $100 \mathrm{~km}$ to the north of Baghdad within Salah al-Din Governorate and its geographical position lies between the longitude $43^{\circ} 55^{\prime} 12^{\prime \prime}-44^{\circ} 28^{\prime} 05^{\prime \prime} \mathrm{E}$ and the latitude $33^{\circ} 30^{\prime} 28^{\prime \prime}-$ $34^{\circ} 03^{\prime} 07^{\prime}$ 'N (Figure-1). The study area is composed of recent and quaternary sediments of Pleistocene-Holocene of the Mesopotamian plain alluvium which consists of thin layers of sand, clayey silt, and silty clay with a succession of clay, sand, and mud, and some gravel within deeper layers. The study area has been heavily used for agricultural purposes[4].The objective of this research is to calculate the heavy elements distribution in the soil of Ishaqi project area using the geoaccumulation index (I-geo), contamination factor (CF), and Pollution load index (PLI).

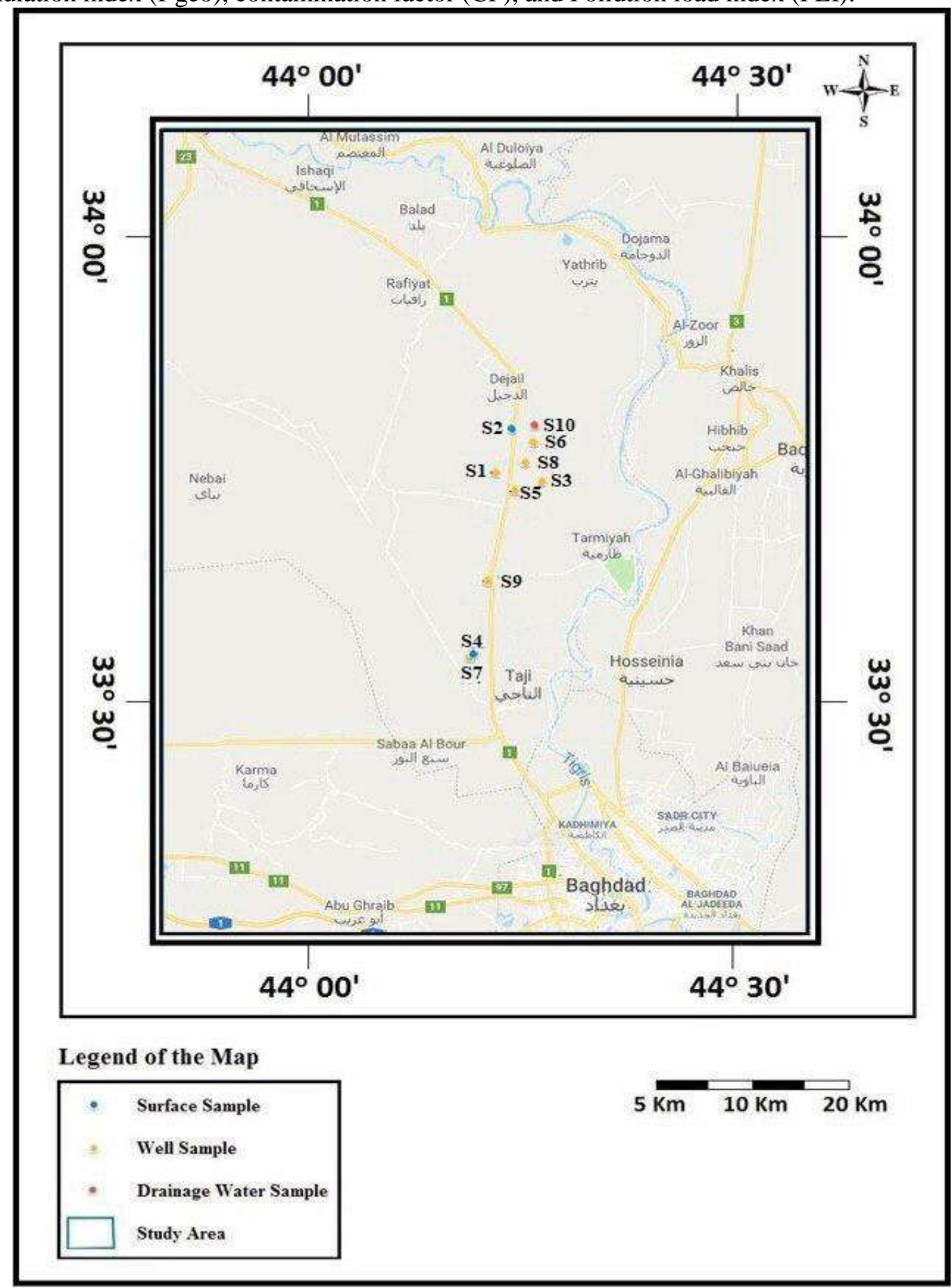

Figure 1-Location map of the soil samples for the study area. 


\section{MATERIALS AND METHODS}

Ten soil samples were selected at depths range of $0-15 \mathrm{~cm}$. from -Ishaqi area during 2018 to evaluate some oxides and heavy elements in the sediments. The selected samples were investigated for $\mathrm{Co}, \mathrm{Zn}, \mathrm{Cu}$, and $\mathrm{Pb}$ elements using three indices; geo-accumulation index (I-geo), contamination factor (CF), and pollution load index (PLI) to detect soil pollution. The natural levels of these chemical constituents were established according to Taylor and McLennan (1985)[5]. All samples were transferred to theGeochemical prep lab - School of environment \& technology /University of Brighton / United Kingdom and laboratory of Geology Department/ University of Baghdad . and subjected to drying processes by an oven at a temperature of $60^{\circ} \mathrm{C}$.Thereafter, five grams of the sediments were powdered to detect $\mathrm{Al} 2 \mathrm{O} 3 \mathrm{CaO}, \mathrm{Na} 2 \mathrm{O}$ and $\mathrm{K} 2 \mathrm{O}$ as well as heavy metals $\mathrm{Co}, \mathrm{Zn}, \mathrm{Cu}$, and $\mathrm{Pb}$ by XRF Methods[6].

The measured heavy metals were used to indicate the pollution by using the mentioned indices. The oxides were used to investigate the intensity of weathering by calculating the Chemical Index of Alteration (CIA) using the formula of Nesbitt and Young( 1982)[7]:

$\mathrm{CIA}=\left(\mathrm{Al}_{2} \mathrm{O}_{3} / \mathrm{Al}_{2} \mathrm{O}_{3}+\mathrm{CaO}+\mathrm{Na}_{2} \mathrm{O}+\mathrm{K}_{2} \mathrm{O}\right) \times 100$

RESULTS AND DISCUSSION

The results of the measured oxides $\left(\mathrm{Fe}_{2} \mathrm{O}_{3} \%, \mathrm{Al}_{2} \mathrm{O}_{3} \%, \mathrm{CaO} \%, \mathrm{Na}_{2} \mathrm{O} \%\right.$, and $\left.\mathrm{K}_{2} \mathrm{O} \%\right)$ and heavy metals concentrations $(\mathrm{Co}, \mathrm{Zn}, \mathrm{Cu}$, and $\mathrm{Pb}$ ) for Ishaqi area are shown in Tables- (1 and 2). Discussion of these chemical constituents is as follows:

A- Heavy Metals and Oxides

Cobalt: Cobalt is an important and essential element for living organisms and is associated with clay minerals [8]. It was found that the mean value of Co concentration was $18.76 \mathrm{ppm}$ in study area Cobalt is present in the same chemical family with $\mathrm{Fe}$ and shows a similar geochemical behaviour so that there is a direct relation of $\mathrm{Co}$ with $\mathrm{Fe}_{2} \mathrm{O}_{3}$. Cobalt with $\mathrm{Al}_{2} \mathrm{O}_{3}, \mathrm{CaO}, \mathrm{Zn}, \mathrm{Cu}$, and $\mathrm{Pb}$ may be adsorbed on the surface of clay and carbonate minerals[9].

Zinc: The agricultural practice is considered as an important source of $\mathrm{Zn}$. Zinc is directly related to $\mathrm{Fe}$ and with clay minerals as one host[9]. It was found that the mean value of $\mathrm{Zn}$ concentration was $114.9 \mathrm{ppm}$ in the study area.

Nickel and zinc are present in the same chemical family of $\mathrm{Fe}$ and show similar geochemical behaviour, so that there is a direct relation with $\mathrm{Fe}_{2} \mathrm{O}_{3}$. The positive relation with $\mathrm{Al}_{2} \mathrm{O}_{3}, \mathrm{CaO}, \mathrm{Cu}$, and $\mathrm{Pb}$ may be due to the adsorption of these two elements on the surface of clay and carbonate minerals [9].

Copper: $\mathrm{Cu}$ is a component of several enzymes and is necessary for the utilization of iron[10]. The mean value of $\mathrm{Cu}$ concentration was $51.78 \mathrm{ppm}$ in Ishaqi area. The sediment content of copper depends on the source rocks, organic matter, clay concentration and PH value [11]. The correlation of copper with the other elements in the samples of the study area showed that it has positive relations with each of $\mathrm{Al}_{2} \mathrm{O}_{3}, \mathrm{Fe}_{2} \mathrm{O}_{3}$, and $\mathrm{CaO}$. These relations may be due to copper adsorption on the surface of clay, iron and carbonate minerals. The direct relation with $\mathrm{Co}$ and $\mathrm{Pb}$ elements may reflect the same source rocks for these elements (mafic rocks).

Lead: The anthropogenic source of $\mathrm{Pb}$ is leaded gasoline. Lead may be found in carbonates, $\mathrm{Fe}-\mathrm{Mn}$ oxides, inorganic matter and clay minerals [9]. $\mathrm{Pb}$ is a toxic metal that is harmful to human health; there is no safe level for lead exposure. The degree of exposure depends on the concentration of lead and route of exposure (air, water, and food)[12]. It was found that the mean value of $\mathrm{Pb}$ concentration was $14.25 \mathrm{ppm}$ in the study area.

Iron oxide: The concentration of $\mathrm{Fe}$ oxides $\left(\mathrm{Fe}_{2} \mathrm{O}_{3}\right)$ in the sediment is related to parent material, degree of weathering, and pedogenic accumulation or depletion processes. Iron is present in opaque mineralsand a in the clay mineral structures such as chlorite, montmorillonite and kaolinite minerals, as well as in the iron minerals[13]. It was found that the mean value of $\mathrm{Fe}_{2} \mathrm{O}_{3} \mathrm{t}$ was $6.11 \%$ in the study area.

Aluminum oxide: Aluminum is a common element in primary silicate minerals, from which it may be released by weathering[13]. Alumina element is present in the clay minerals structure. In addition, it is found as $\mathrm{Al}(\mathrm{OH})_{2}$ between the layers of montmorillonite or adsorbs on clay minerals[14]. It was found that the mean value of $\left(\mathrm{Al}_{2} \mathrm{O}_{3}\right)$ was $8.75 \%$ in thestudy area.

Calcium oxide: Calcium oxide is common in primary carbonate minerals, from which it may be released by weathering. There is a correlation of $\mathrm{CaO}$ with the other oxides in the sediments; it has 
direct relations with $\mathrm{Fe}_{2} \mathrm{O}_{3}$ and $\mathrm{Al}_{2} \mathrm{O}_{3}$, and these relations may be attributed to the association of these metals in the clay minerals. It was found that the mean value of $(\mathrm{CaO})$ was $17.18 \%$ in thestudy area.

Sodium oxide: Sodium oxide content in the samples is due to its relation with clay minerals especially montmorillonite [15]. Navratilova and Kula (2000) showed that sodium element was considered as a major element in the montmorillonite minerals [16]. Also, Gregor (1976) reported that sodium element is fixed in the clay minerals by institution of potassium by sodium element. This study also mentioned the ability of sodium element to adsorb on clay minerals in the basic condition [17]. It was found that the mean value of $\mathrm{Na}_{2} \mathrm{O}$ was $1.26 \%$ in thestudy area.

Potassium oxide: It was found that the mean percent of $\mathrm{K}_{2} \mathrm{O}$ was $1.44 \%$ in the study area. The correlation of $\mathrm{K}_{2} \mathrm{O}$ with the other oxides in the sediments of the study area reflected an indirect relation with $\mathrm{Fe}_{2} \mathrm{O}_{3}$, and $\mathrm{Na}_{2} \mathrm{O}$, due to the lack of potassium element and carbonate minerals in the clays.

Table 1-Results of oxides and heavy elements in the soil of the study area

\begin{tabular}{|c|c|c|c|c|c|c|c|c|c|}
\hline $\mathrm{No}$ & $\mathrm{fe}_{2} \mathrm{O}_{3}$ & $\mathrm{Al}_{2} \mathrm{O}_{3}$ & $\mathrm{CaO}$ & $\mathrm{Na}_{2} \mathrm{O}_{3}$ & $\mathrm{~K}_{2} \mathrm{O}$ & $\mathrm{Co}$ & $\mathrm{Zn}$ & $\mathrm{Cu}$ & $\mathrm{Pb}$ \\
\hline $\mathbf{1}$ & 6.39 & 9.257 & 17.99 & 0.769 & 1.444 & 23.4 & 109.1 & 55.1 & 13.1 \\
\hline $\mathbf{2}$ & 6.477 & 9.324 & 17.15 & 1.014 & 1.527 & 25 & 112 & 51.5 & 13 \\
\hline $\mathbf{3}$ & 6.02 & 8.701 & 16.17 & 0.875 & 1.43 & 18.2 & 118 & 49.6 & 13.6 \\
\hline $\mathbf{4}$ & 6.097 & 8.456 & 19.26 & 0.723 & 1.299 & 12.9 & 103.7 & 54 & 12.9 \\
\hline $\mathbf{5}$ & 6.394 & 9.454 & 16.76 & 1.23 & 1.511 & 22.9 & 117 & 53.2 & 13.8 \\
\hline $\mathbf{6}$ & 6.433 & 9.385 & 15.74 & 0.969 & 1.645 & 32.5 & 117.6 & 54.9 & 15.5 \\
\hline $\mathbf{7}$ & 6.077 & 8.606 & 18.56 & 1.153 & 1.403 & 15.2 & 103 & 49.7 & 12.8 \\
\hline $\mathbf{8}$ & 5.029 & 7.343 & 17.13 & 2.534 & 1.332 & 9.3 & 140.8 & 46.2 & 19.8 \\
\hline $\mathbf{9}$ & 6.003 & 8.334 & 16.45 & 1.906 & 1.491 & 10.8 & 112.1 & 51.6 & 15.3 \\
\hline $\mathbf{1 0}$ & 6.252 & 8.725 & 16.67 & 1.503 & 1.41 & 17.4 & 115.7 & 52 & 12.7 \\
\hline Mean & 6.1172 & 8.7585 & 17.188 & 1.2676 & 1.4492 & 18.76 & 114.9 & 51.78 & 14.25 \\
\hline Min & 5.029 & 7.343 & 15.74 & 0.723 & 1.299 & 9.3 & 103 & 46.2 & 12.7 \\
\hline Max & 6.477 & 9.454 & 19.26 & 2.534 & 1.645 & 32.5 & 140.8 & 55.1 & 19.8 \\
\hline
\end{tabular}

\section{B- Assessment of contamination:}

In this research, three soil pollution indices were selected to assess the contamination level of Co, $\mathrm{Zn}$, $\mathrm{Cu}$, and $\mathrm{Pb}$ in the soil of study

area. These are the Geo accumulation index (I-geo), contamination factor (CF) and Pollution Load Index (PLI) (Tables- 2 and 3).

\section{1- Geo-accumulation index (I-geo)}

This index is used for comparing the levels of the analysed heavy elements to the background level. Igeo was determined by the following equation according to Taylor and McLennan (1985) Muller (1969):

I- geo $=\log 2(\mathrm{Cn} / 1.5 \mathrm{Bn})$ Where:

$\mathrm{Cn}=$ the analysed value of the heavy elements in the samples and

$\mathrm{Bn}=$ the crustal average background concentration of the heavy elements (Taylor and McLennan, 1985; Lu et al., 2009).

$\mathrm{Lu}$ et al (2009)[18] defined the constant 1.5 as a constant introduced to minimize the effect of possible variations in the background values which may be attributed to lithological variations in the sediments. Muller (1969)[19] designed a classification for the Geoaccumulation index. This application was considered by many researchers like Huu et al (2010)[20]. The values of this index vary from sub-zero to more than 5 having 7 grades (Table- 3). The highest grade (6) reflects a 100fold enrichment and (0) reflects the background concentration according to Table-3. The values of this index have seven grades and the results reflected the following: The value for $\mathrm{Pb}$ was found negative in study area, ranging from - $0.20--0.9$ (Table-3). The result indicates that the study area is unpolluted by $\mathrm{Pb}$. I geo values of $\mathrm{Cu}$ in Ishaqi area ranged from 0.2 to 0.5 indicating slightly polluted 
sediments by $\mathrm{Cu}$. the I-geo value of $\mathrm{Zn}$ in the study area ranged from -0.0 to 0.1 , indicating that these samples are slightly polluted. I-geo value for Co were in Ishaqi area ranged from -0.0 to- -1.4 and were considered as unpolluted sediments by Co.

\section{2- Contamination factor $(\mathbf{C F})$}

The contamination factor (CF) was determined according to Thomilson et al. (1980) equation.

$\mathrm{CF}=\mathrm{Cm}$ Sample/ Cm Background

Where:

CF: contamination factor.

Cm Sample: metal content in the sample.

$\mathrm{Cm}$ Background: background level of metal.

The contamination factor (CF) for $\mathrm{Co}, \mathrm{Zn}, \mathrm{Cu}$, and $\mathrm{Pb}$ was calculated in the Ishaqi area (Table-3). The values of $\mathrm{pb}$ in the ten sites ranged from 0.7 to 1.2 , reflecting low to moderate contamination with. Lead is known to come from the use of high lead gasoline[9]. $\mathrm{CF}$ for $\mathrm{Cu}$ in Ishaqi area ranged from 1.8to 2.2 indicating moderate contamination (class 2 ). $\mathrm{Zn}$ in the study area was classified as class 2 , representing moderate contamination ranging from 1.4 to 1.9. $\mathrm{Zn}$ originates from toxic waste from industrial sources[21]. Cobalt (Co) in the study area is represented low to moderate contamination, as class 2, ranging from 0.5 to 1.9 . (Table-3).

It is believed that a considerable part of heavy elements find its way into the environment as a result of the burning of diesel oil and may be due to the disposal of heavy elements -containing wastewater.

3- Pollution load index (PLI) The pollution load index (PLI) was determined according to Thomilson et al. (1980) [22] equation, where (PLI) is expressed as follows:

$\mathrm{PLI}=\mathrm{n} \sqrt{\mathrm{CF}} 1 \times \mathrm{CF} 2 \times \mathrm{CF} 3 \times \ldots . . \mathrm{CF} n$

Where:

$\mathrm{n}=$ the number of analyzed metals in each site.

The Pollution Load Index (PLI) for $\mathrm{Co}, \mathrm{Zn}, \mathrm{Cu}$, and $\mathrm{Pb}$ was calculated, and the samples were classified as class 2 (Deterioration on-site quality), indicating local pollution. PLI values in the study area ranged from 1.1 to1.6 (Table-3). Higher values of PLI factor may result from the effects of untreated toxic waste that discharges to the drainage from the domestic areas, along with some anthropogenic activities that contaminate the soil by heavy metals.

Table 2-Results of the soil pollution indices; geo-accumulation (I-geo), contamination factor (CF), and pollution load index (PLI)values of the study area.

\begin{tabular}{|c|c|c|c|c|c|c|c|c|c|c|c|c|c|}
\hline $\begin{array}{l}\text { Samp } \\
\text { le no }\end{array}$ & PLI & $\begin{array}{c}\text { Co } \\
(\mathbf{p p m})\end{array}$ & I geo & CF & $\underset{(\mathbf{p p m})}{\mathbf{Z n}}$ & I geo & CF & $\underset{(\mathbf{p p m})}{\mathbf{C u}}$ & I geo & CF & $\begin{array}{c}\mathbf{P b} \\
(\mathbf{p p m})\end{array}$ & I geo & CF \\
\hline 1 & 1.40 & 23.4 & -0.12 & 1.38 & 109.10 & 0.03 & 1.54 & 55.10 & 0.55 & 2.20 & 13.10 & -0.87 & 0.82 \\
\hline 2 & 1.40 & 25 & -0.03 & 1.47 & 112.00 & 0.07 & 1.58 & 51.50 & 0.45 & 2.06 & 13.00 & -0.88 & 0.81 \\
\hline 3 & 1.32 & 18.2 & -0.49 & 1.07 & 118.00 & 0.15 & 1.66 & 49.60 & 0.40 & 1.98 & 13.60 & -0.82 & 0.85 \\
\hline 4 & 1.18 & 12.9 & -0.98 & 0.76 & 103.70 & -0.04 & 1.46 & 54.00 & 0.52 & 2.16 & 12.90 & -0.90 & 0.81 \\
\hline 5 & 1.42 & 22.9 & -0.16 & 1.35 & 117.00 & 0.14 & 1.65 & 53.20 & 0.50 & 2.13 & 13.80 & -0.80 & 0.86 \\
\hline 6 & 1.61 & 32.5 & 0.35 & 1.91 & 117.60 & 0.14 & 1.66 & 54.90 & 0.54 & 2.20 & 15.50 & -0.63 & 0.97 \\
\hline 7 & 1.20 & 15.2 & -0.75 & 0.89 & 103.00 & -0.05 & 1.45 & 49.70 & 0.40 & 1.99 & 12.80 & -0.91 & 0.80 \\
\hline 8 & 1.26 & 9.3 & -1.46 & 0.55 & 140.80 & 0.40 & 1.98 & 46.20 & 0.29 & 1.85 & 19.80 & -0.28 & 1.24 \\
\hline 9 & 1.19 & 10.8 & -1.24 & 0.64 & 112.10 & 0.07 & 1.58 & 51.60 & 0.45 & 2.06 & 15.30 & -0.65 & 0.96 \\
\hline 10 & 1.29 & 17.4 & -0.55 & 1.02 & 115.70 & 0.12 & 1.63 & 52.00 & 0.46 & 2.08 & 12.70 & -0.92 & 0.79 \\
\hline
\end{tabular}


Table 3-Classified grades of I-geo, CF and PLI indices (afterThomilson et al., 1980)

\begin{tabular}{|l|l|l|}
\hline \multicolumn{1}{|c|}{ I-geo } & \multicolumn{1}{c|}{ CF contamination factor } & \multicolumn{1}{c|}{ PLI } \\
\hline $\begin{array}{l}\leq 0 \text { (class 0), Practically } \\
\text { unpolluted }\end{array}$ & & $<1$ Perfection (class 0) \\
\hline $\begin{array}{l}0<\text { to } \leq 1 \text { (class 1), slightly } \\
\text { polluted }\end{array}$ & $\begin{array}{l}<1 \text { Low contamination } \\
\text { (Class } 1) .\end{array}$ & $=1$ Baselinelevel (Class 1) \\
\hline $\begin{array}{l}1<\text { to } \leq 2 \text { (class 2), } \\
\text { Moderately polluted }\end{array}$ & $\begin{array}{l}1 \leq \mathrm{CF}<3 \text { Moderatecontamination } \\
\text { (class 2). }\end{array}$ & $\begin{array}{l}>1 \text { Deteriorationon site } \\
\text { Quality (class 2) }\end{array}$ \\
\hline $\begin{array}{l}2<\text { to } \leq 3 \text { (class 3), } \\
\text { moderately severely } \\
\text { polluted }\end{array}$ & $\begin{array}{l}3 \leq \mathrm{CF} \leq 6 \text { Considerable } \\
\text { Contamination (class 3). }\end{array}$ & \\
\hline $\begin{array}{l}3<\text { to } \leq 4 \text { (class } 4), \\
\text { Severely polluted }\end{array}$ & $>6$ Very high & \\
\hline $\begin{array}{l}4<\text { to } \leq 5 \text { (class 5), } \\
\text { Severely extremely polluted }\end{array}$ & & \\
\hline $\begin{array}{l}>5 \text { (class 6), Extremely } \\
\text { polluted }\end{array}$ & & \\
\hline
\end{tabular}

\section{CONCLUSIONS}

The concentrations of heavy metals $(\mathrm{Co}, \mathrm{Zn}, \mathrm{Cu}$, and $\mathrm{Pb})$ found in the study area can mainly be due to the relatively high percentages of clay contamination . Moreover, pollution with these heavy elements is thought to be due to different sources such as urban wastes, fertilizers, etc. It is clear that the pollutants affected Ishaqi area soil that have relatively high clay.

\section{References}

1. Gowd, S.S., Reddy, M.R. and Govil, P.K. 2010. Assessment of heavy metal contamination in soils at Jajmau (Kanpur) and Unnao industrial areas of the Ganga Plain, Uttar Pradesh, India. $J$. Hazardous Mat. 174: 113 - 121.

2. Kabata-Pendias, A. and Mukherjee, A.B. 2007. Trace Elements from Soil to Human. SpringerVerlag Berlin Heidelberg, 561.

3. Khwedim, K.H., Al-Anssari, H.R. and Al-Bassam, K. 2009. Study of distribution of some heavy metals in the soil of Basra city-south of Iraq", Iraqi Journal of Science, 50: 533 - 542.

4. Jassim, S.Z. and Goff, J.C. 2006. Geology of Iraq. 1st edition, printed in Czech Republic., 318.

5. Taylor, S.R., and McLennan, S.M. 1985. The continental crust: its composition and evolution, Blackwell, Oxford.

6. Aubert, H. and Pinta, M. 1977. Trace elements in soils, Developments in soil science, Elsevier sc.ientific Publishing Co., Amsterdam, 395.

7. Nesbitt, H.W. and Young, G.M. 1982. Early Proterozoic Climate and Plate Motion Inferred from Major Element Chemistry of sites. Nature, 299: 715 - 717.

8. Hem, J.D. 1985. Study and interpretation of the chemical characteristics of natural water (3rd ed.). USGS water- supply papers-2254, 253

9. Pendias, K.A. and Pendias, H. 2001. Trace Elements in Soils and Plants. 3rd edition, CRC Press, Boca Raton, London, N. Y., Washington, D.C., USA, 388.

10. Williams, L. D. 2005. Environmental Science Demystified, McGraw-HILL publisher. 413p.

11. Aubert, H. and Pinta, M. 1977. Trace elements in soils, Developments in soil science, Elsevier scientific publishing Co., Amsterdam, 395.

12. Hem, J.D. 1991. Study and interpretation of the chemical characteristics of natural water, U.S. Geological Survey, Water Supply, paper- 2254, 263.

13. Kabata-Pendias, A. and Sadurski, W. 2004. Trace elements and compounds in soil. In: Merian E, Anke M, Ihnat M, Stoepppler M (eds) Elements and their compounds in the environment, WileyVCH, Weinheim, 2nd ed., $79-99$.

14. Jenne, E.A. 1968. Controls on $\mathrm{Mn}, \mathrm{Fe}, \mathrm{Co}, \mathrm{Ni}, \mathrm{Cu}$, and $\mathrm{Zn}$. Concentration in soils and water; the significant roles of hydrous Mn\& Fe Oxides In: Trace inorganics in water. Adf. Chem. ser., 67: $337-387$. 
15. Weaver, C.E. and Pollared, D. E. 1975. The chemistry of clay minerals. Development in sedimentology, part 15, Elsevier scientific publ. Co., New York, 213.

16. Navratilova, Z. and Kula, P. 2000. Study of the ion exchange on vermiculite by means of carbon paste electrode.Univ. Masrayk. Brno, 28(29): 43 - 54.

17. Gregor, C.B. 1976. The geochemical behavior of sodium brokering. Holland V.N Amsterdam.

18. Lu, X.L., Wang, K., Lei, J.H.andZhai, Y., 2009. Contamination assessment ofcopper, lead, zinc,manganese, and nickel in street dust of Baoji, NW China, J. Hazardous Mat. 161: 1058-1062.

19. Muller, G. 1969. Index of accumulation in sediments of the RhinelRiver, J. Geol. 2: 108-118.

20. Huu, H.H.; Rudy, S. and Damme, A.V. 2010. Distribution and contamination status of heavy metalsin estuarine sediments near CauOng harbor, Ha Long Bay, Vietnam. Geol.Belgica 13(12):37-47.

21. Thorpe, A., and Harrison, R.M. 2008. Sources and properties of non- exhaust particulate matter from road traffic: a review. Sci Total Environ 400: 566 - 575.

22. Thomilson, D.C., Wilson, D.J., Harris, C.R. and Jeffrey, D.W. 1980. The problem in heavy metals in estuaries and the formation of a pollution index. Helgol. Wiss. Meeresunlter. 33: $566-575$. 